\title{
$\mathrm{PH} \mathbf{1 0 2}$ debate
}

a debate Comunicación y redes sociales en instituciones culturales

| coordina Candela González Sánchez

\section{RedesCOAs, un proyecto colectivo de difusión institucional}

Leyre Salgado, Nuria López, Samuel González | Dpto. de Comunicación, Consejo Superior de los Colegios de Arquitectos de España (CSCAE)

URL de la contribución <www.iaph.es/revistaph/index.php/revistaph/article/view/4826>

La comunicación institucional de los colegios de arquitectos de España, así como la de su Consejo Superior, está estrechamente ligada a la difusión cultural y pedagógica de los valores de la arquitectura como garante de la calidad de vida de las personas, un aspecto que ha quedado más en evidencia, si cabe, este año con la crisis derivada de la Covid19 y la experiencia del confinamiento.

En este sentido, las redes sociales, más que instituciones de cultura per se, se han configurado como canales de comunicación fundamentales para dar voz a aspectos de la realidad que no siempre tenían cabida en el circuito mediático.

Creada en 2016, la red de comunicación de los Colegios de Arquitectos de España, RedesCOAs, se ha consolidado como un instrumento imprescindible para amplificar el alcance de la labor institucional que realizan el CSCAE y los colegios como principales operadores de la cultura arquitectónica en nuestro país, y en estos últimos meses, además, para cubrir las necesidades de información inmediata que ha generado la crisis. Integrada por más de 30 perfiles online, RedesCOAs es una herramienta al servicio de los colegios de arquitectos y de los/ as colegiados/as, pero de ella se beneficia el conjunto de la sociedad, ya que la red expande el mensaje unificado de la profesión.

En estos cinco años de existencia ha ido rompiendo barreras y consolidando su implantación; ayudando de forma muy eficaz no solo a la difusión de la dimensión política de la institución, sino también multiplicando el alcance de todos los proyectos culturales que promueven los colegios de arquitectos de España -jornadas como el Día Mundial de la Arquitectura, la puesta en marcha de la plataforma web AgendaArquitectura,
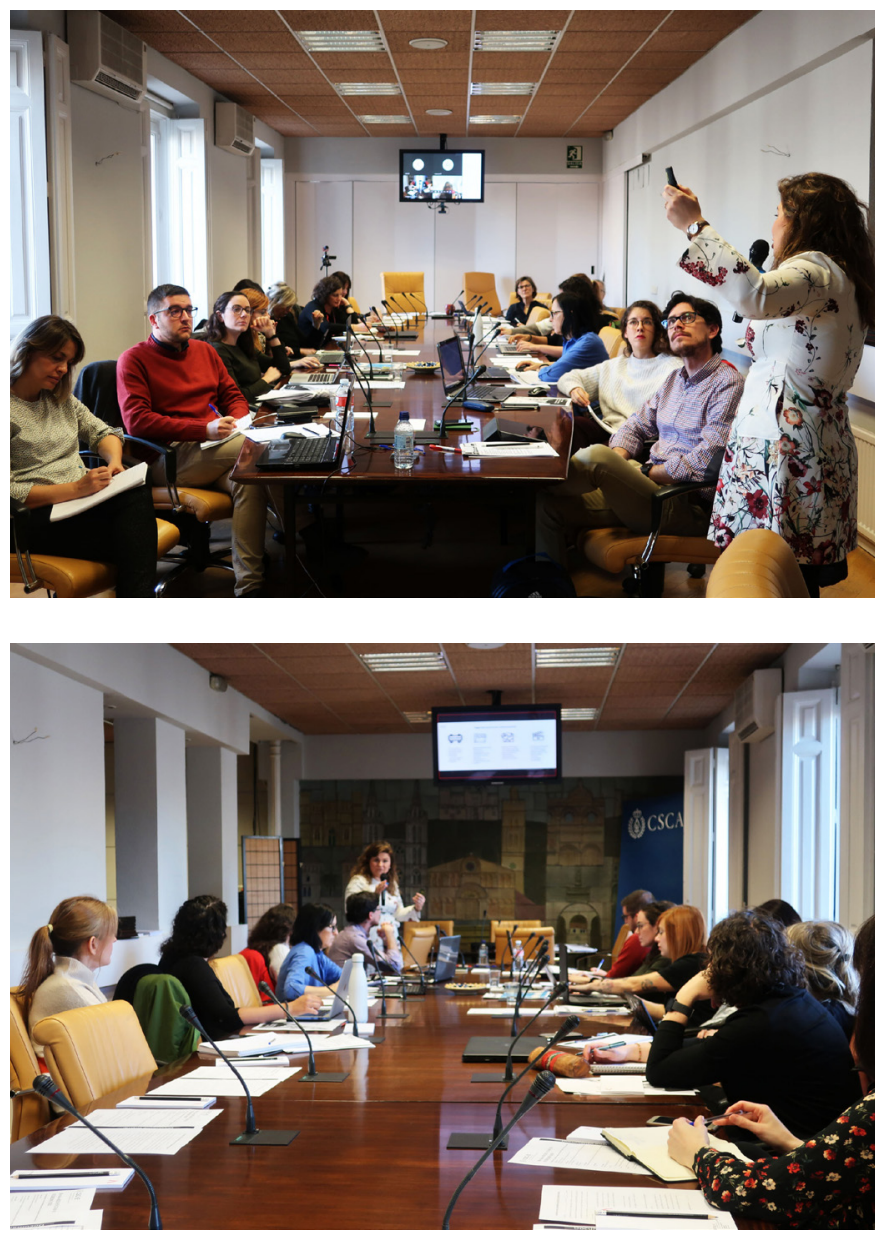

Reunión presencial de RedesCOAs en febrero de 2020 en la sede del CSCAE | fotos CSCAE

foros de debate, exposiciones, etcétera-, que logran un mayor alcance del que tendrían si su difusión se limitara al ámbito local en el que se circunscriben.

Existe, sin duda alguna, una comunidad que demanda la defensa de la cultura y su difusión a través de los medios de comunicación, y las redes sociales son uno de los 
canales más importantes para atender esta demanda. La sociedad exige cultura, aun cuando los mensajes más agoreros nos puedan hacer pensar que existe desconexión popular con ella. En el caso de RedesCOAs y nuestros proyectos, el éxito de convocatoria en las jornadas de la Semana de la Arquitectura o el uso de la web AgendaArquitectura nos reafirma en la necesidad de seguir apostando por la implicación de las instituciones colegiales en este ámbito.

Las bienales de arquitectura o el certamen EUROPAN para jóvenes arquitectos (que impulsa el Ministerio de Transportes, Movilidad y Agenda Urbana y en los que el CSCAE ocupa la Secretaría) son otras convocatorias en las que hemos comprobado lo importante que es acompañar su difusión no solo desde la dimensión de concurso arquitectónico, sino también como encuentros culturales y de desarrollo para la mejora de la vida de las personas. La arquitectura, no lo olvidemos, ocupa el 100 $\%$ de nuestro día a día. Forma parte de nuestra realidad y esta no solo se limita al espacio que habitamos, siendo los edificios el ejercicio último de su expresión. Influye en el lugar en el que nos movemos, desplazamos o relacionamos y, como institución, así debemos trasladarlo y defenderlo.

Como Consejo Superior de los Colegios de Arquitectos de España, hemos aprendido que es muy importante el mensaje unificado y coordinado en redes sociales, así como la implicación activa de nuestros perfiles en la comunidad de usuarios que solicita nuestros contenidos. Además, una vez que una institución tiene presencia en medios sociales no puede ni debe alejarse de ellos: son una de las mejores vías de comunicación directa y bidireccional con el receptor de nuestros servicios. Poder explicar de primera mano e interactuar con los receptores también ayuda a modular proyectos y mejorarlos, detectando qué es lo que funciona y qué es lo que siempre puede ser mejorable para poder dar en cada momento un servicio a la sociedad útil y de calidad; esa es nuestra misión como comunicadoras del CSCAE. 